Mirko Pejanović, Sarajevo

\title{
UVODNI PRILOG POVODOM JUBILEJA 75. GODINA ŽIVOTA AKADEMIKA IVANA CVITKOVIĆA
}

Od 2012. godine, kao redovni član Akademije nauka i umjetnosti Bosne i Hercegovine, akademik Ivan Cvitković obavlja dužnost sekretara Odjeljenja društvenih nauka Akademije nauka i umjetnosti Bosne i Hercegovine.

Odjeljenje društvenih nauka ANUBiH u svom programu rada za 2020. godinu je iniciralo obilježavanje jubileja 75 . godina života akademika Ivana Cvitkovića. U želji da se, u okviru obilježavanja 75. godina života akademika Ivana Cvitkovića, osvijetli naučni opus i doprinos teorijskom utemeljenju sociologije religije u Bosni i Hercegovini, 2020. godine u ANUBiH je pripremljen zbornik: "Doprinos akademika Ivana Cvitkovića razvoju sociologije religije", nakon čije će promocije biti upriličeno kratko druženje sa akademicima i prijateljima akademika Ivana Cvitkovića. Istaknuti autori iz postjugoslovenskih zemalja u oblasti sociologije religije napisali su svoje autorske priloge za planirani zbornik radova povodom 75 . godina života i višedecenijskog naučnog i pedagoškog rada akademika Ivana Cvitkovića.

U prigodnom uvodnom tekstu za zbornik posvećen 75. godišnjici života akademika Ivana Cvitkovića uključeni su ovi aspekti: Biografija; Uvid u bibliografiju objavljenih radova; Doprinos zasnivanju naučno-nastavne discipline sociologije religije na Fakultetu političkih nauka Univerziteta u Sarajevu te vrednovanje doprinosa akademika Ivana Cvitkovića u tekstovima istaknutih sociologa o teorijskom izučavanju i empirijskom istraživanju u oblasti sociologije religije. O doprinosu izučavanju sociologije religije akademika Ivana Cvitkovića autorske tekstove povodom 75. godišnjice života akademika Ivana Cvitkovića i njegovog doprinosa razvoju sociologije religije napisali su: prof. dr. Đuro Šušnjić, akademik Slavo Kukić, prof. dr. Marko Kerševan, prof. dr. Dragoljub B. Đorđević, prof. dr. Dino Abazović, domaći član ANUBiH prof. dr. Ivan Markešić, doc. dr. Zilka Spahić Šiljak, prof. dr. Ružica Cacanoska, prof. dr. Dragan Todorović, prof. dr. Sergej Flere i prof. dr. Zorica Kuburić. 
Akademik Ivan Cvitković je rođen 5. 5. 1945. godine u gradu Mostaru. Osnovnu i srednju učiteljsku školu završio je u rodnom gradu. Studij sociologije je pohađao na Fakultetu političkih nauka Univerziteta u Sarajevu. Nakon što je završio studij sociologije 1967. godine upisuje se na postdiplomski studij na Fakultetu političkih znanosti u Zagrebu, i to iz oblasti teorije ateizma i religije. Magistarski rad na temu "Katolička crkva i omladina u urbanim sredinama Bosne" odbranio je 1974. godine. Akademik Ivan Cvitković svoj doktorski rad na temu "Marksistička misao i religija" odbranio je 1978. godine na Fakultetu za sociologiju, novinarstvo i političke znanosti u Ljubljani.

Karijeru univerzitetskog nastavnika akademik Ivan Cvitković započinje izborom za asistenta na Fakultetu političkih nauka Univerziteta u Sarajevu 1972. godine. Potom je uslijedio izbor za docenta 1980. godine. Od 1986. godine postaje vanredni profesor. Za redovnog profesora na predmetima Sociologija religije, Sociologija spoznaje i morala te Religije savremenog svijeta izabran je 1989. godine na Odsjeku za sociologiju Fakulteta političkih nauka. Po odlasku u mirovinu 2013. godine dobio je zvanje profesora emeritusa.

Od 2008. godine je dopisni član Akademije nauka i umjetnosti Bosne i Hercegovine, a od 2012. godine je redovni član. U ulozi sekretara Odjeljenja društvenih nauka pokretač je i nosilac realizacije više istraživačkih projekata i naučnih skupova u Akademiji nauka i umjetnosti Bosne i Hercegovine. Od 2012. do 2020. godine Odjeljenje društvenih nauka je organizovalo dvije međunarodne naučne konferencije. Jedna je bila posvećena Dejtonskom mirovnom sporazumu i budućnosti Bosne i Hercegovine. Zbornik radova s ove konferencije štampan je 2016. godine pod naslovom "Dejtonski mirovni sporazum i budućnost Bosne i Hercegovine”. Druga međunarodna naučna konferencija bila je posvećena 75. godišnjici Prvog zasjedanja ZAVNOBIHa. U radu naučne konferencije učešće je uzelo preko 30 naučnih radnika i istraživača, među kojima su bili i istraživači iz inostranstva. Nakon održane konferencije objavljen je zbornik radova pod naslovom “75. godišnjica Prvog zasjedanja ZAVNOBiH-a: povijesna utemeljenost obnovljene državnosti Bosne i Hercegovine u XX i XXI stoljeću".

Održano je i više okruglih stolova, od kojih je posebnu pažnju u stručnoj i naučnoj javnosti dobio okrugli sto o geopolitičkim promjenama u svijetu i Evropi i položaju Bosne i Hercegovine. Zbornik radova s okruglog stola objavljen je 2017. godine.

Članovi Odjeljenja društvenih nauka su uradili više studija, na temelju Popisa stanovništva 2013. godine, o demografskim i etničkim promjenama. Ove studije su štampane 2017. godine u zborniku radova ANUBiH pod naslovom: "Demografske i etničke promjene u BiH". 
U organizaciji Odjeljenja društvenih nauka provodi se više istraživanja. Tokom 2018. i 2019. godine završena je i štampana istraživačka studija "Sarajevo grad i regija". U toku je obrada empirijske građe na projektu: "Koliko se poznajemo".

Akademik Ivan Cvitković je u svom nastavnom i naučnoistraživačkom radu postigao zapažene rezultate. Objavio je 36 knjiga u autorstvu, a 5 knjiga u koautorstvu. Knjiga: "Sociologija religije" imala je četiri izdanja, a knjiga: "Religije suvremenog svijeta" tri izdanja. Svoje referate izložene na naučnim skupovima i simpozijima u Bosni i Hercegovini i inostranstvu objavio je u 58 zbornika i publikacija.

Napisao je više članaka i studija koji su objavljeni u 94 domaća i inostrana časopisa. Objavio je 35 recenzija i prikaza knjiga većeg broja autora iz oblasti sociologije religije.

U naučnom opusu akademika Ivana Cvitkovića je i autorstvo "Rječnika religijskih pojmova", štampanog u dva izdanja. Autor je i šest odrednica za Hrvatsku enciklopediju BiH i Sociološkog rječnika u izdanju Zavoda za udžbenike Beograd.

Bio je rukovodilac izrade više istraživačkih studija. Među njima je istraživanje "Religijski i nacionalni odnosi na selu", izvedeno 1987. godine u organizaciji Instituta za proučavanje nacionalnih odnosa. Posebno mjesto u istraživačkom radu imalo je teorijsko istraživanje "Društvena misao u pisanim religijskim autoritetima", završeno 1994. godine. Istraživački projekat "Nacija i konfesija u ratu" objavljen je kao knjiga 2004. godine pod istim naslovom. Za ovu knjigu akademik Ivan Cvitković je dobio nagradu Fakulteta političkih nauka za najbolju knjigu u 2004. godini.

Akademik Ivan Cvitković je ostvario aktivnost u članstvu više redakcija časopisa: Lica (Sarajevo), Porodica i dijete (Sarajevo), Opredjeljenja (Sarajevo), Etos (Sarajevo), Religija i tolerancija (Novi Sad), Radovi (Sarajevo), Diskurs (Sarajevo), Balkan Science Review (Štip, Makedonija).

Tokom svog višedecenijskog nastavno-naučnog i pedagoškog rada akademik Ivan Cvitković je zasnovao naučnu disciplinu sociologija religije na Odsjeku za sociologiju na Fakultetu političkih nauka Univerziteta u Sarajevu. O tome u svojoj knjizi "Sociološki pogledi na naciju i religiju III", štampanoj 2017. godine akademik Ivan Cvitković zapisuje (na str. 236) kako se sociologija religije u Bosni i Hercegovini počela kasno razvijati, dugo je bila u okviru sociologije kulture. Potom potcrtava: "Ponosan sam na to što mogu slobodno reći kako sam prvi u Bosni i Hercegovini razvio sociologiju religije kao zasebnu sociološku disciplinu na Odsjeku za sociologiju Fakulteta političkih nauka u Sarajevu." Nadalje, akademik Ivan Cvitković ističe da su mu 
put za to utrli njegovi prethodnici: Ante Fiamengo, a najviše profesor Esad Ćimić, koji je u okviru predmeta Sociologija kulture jedan semestar predavao i sociologiju religije. Uz sociologiju religije, akademik Ivan Cvitković je utemeljio silabuse i za nove sociološke discipline kao što su: sociologija spoznaje i morala te religije suvremenog svijeta. Kao istaknuti naučni radnik i istraživač, akademik Ivan Cvitković, uz profesorsku ulogu na Fakultetu političkih nauka, bio je imenovan 2007. godine za direktora Religijskih studija na Centru za interdisciplinarne studije Univerziteta u Sarajevu.

Svi autorski prilozi napisani povodom jubileja 75. godina života akademika Ivana Cvitkovića elaboriraju njegov doprinos razvoju sociologije religije. Postoji saglasnost u mišljenju autora priloga: akademika Slave Kukića, prof. dr. Marka Kerševana, prof. dr. Sergeja Flerea, prof. dr. Đure Šušnjića, prof. dr. Dragoljuba B. Đorđevića, prof. dr. Ivana Markešića, prof. dr. Ružice Cacanovske, prof. dr. Dragana Todorovića, prof. dr. Dine Abazovića i doc. dr. Zilke Spahić Šiljak, da je akademik Ivan Cvitković svojim naučnoistraživačkim radom i ukupnim stvaralačkim opusom postao vodeći sociolog religije u Bosni i Hercegovini i šire u regiji Jugoistočne Evrope.

U svom prilogu pod naslovom "Akademik Ivan Cvitković: istaknuti sociolog religije i istinski humanista" profesor Dragoljub B. Đorđević sa Univerziteta u Nišu pravi osvrt na tri autorska djela akademika Ivana Cvitkovića i izlaže najvažnije segmente iz područja naučno-stručne saradnje sa profesorom Ivanom Cvitkovićem u 90-im godinama XX stoljeća i prvim decenijama XXI stoljeća. U fokus svoga osvrta na doprinos akademika Ivana Cvitkovića razvoju sociologije religije prof. dr. Dragoljub B. Đorđević uvrštava ove knjige koje naziva miljenicama: "Rječnik religijskih pojmova" iz 1991. godine, "Marksistička misao i religija" iz 1980. godine, "Sociologija religije" iz 1995. godine sa četiri izdanja, "Konfesija u ratu" iz 2004. godine i "Društvena misao u svetim spisima" iz 1997. godine. Kad se pojavio "Rječnik religijskih pojmova”, prof. dr. Dragoljub B. Đorđević piše kritički prikaz za časopis Nissa. U svom stajalištu o Rječniku religijskih pojmova prof. dr. Dragoljub B. Đorđević naglašava: "Iako knjiga profesora Cvitkovića nije enciklopedijskog karaktera, već u pravom smislu rečnik sa brojnim, a kratkim leksikografskim određenjima, ona se pojavila, kako vidimo, u pravo vreme. Vrlo je važno da se i tada i sada pojavljuje u jednom multikonfesionalnom društvu kao što je Bosna i Hercegovina, da je Cvitković ravnopravno, koliko je to bilo moguće, podelio odrednice koje pripadaju trima poznatim religijama i konfesijama na ovom prostoru: islamu, katoličanstvu i pravoslavlju."

Povodom 1700 godina od proglašenja Milanskog edikta i slavljenja ovog velikog jubileja u hrišćanskom svijetu, akademik Cvitković je pripremio i 
izložio svoj referat na naučnom skupu 2013. godine. Prof. dr. Dragoljub B. Đorđević tim povodom ističe: "On (Cvitković) je primer sociologa religije koji se zalaže za mir i toleranciju, dijalog i ekumenizam, što i nije iznenađenje za naučnika koji je ceo svoj život i radni vek proveo na trusnom području Bosne i Hercegovine, zemlje u kojoj se susreću dve otkrivene religije - hrišćanstvo i islam - i gde se prepliću dve hrišćanske konfesije: pravoslavlje i katoličanstvo."

U autorskom prilogu "Teorijsko i istorijsko - razumevanje religiozne vere i nevere" prof. dr. Đuro Šušnjić iz Beograda polazi od stajališta da sve ljudske zajednice imaju religiju, ali nemaju sve istu religiju. Sva teorijska razmatranja i teorijske sinteze empirijskih istraživanja akademika Ivana Cvitkovića u oblasti sociologije religije prof. dr. Đuro Šušnjić analizira u filozofskom društveno-istorijskom kontekstu postojanja vjerovanja, vjere i religijskih zajednica u savremenom svijetu. Svjestan različitih zamki Ivan Cvitković, prema zapažanju profesora Šušnjića, teži da dublje rasvijetli pojam religije. Prof. Šušnjić uočava da akademik Ivan Cvitković "pokazuje i dokazuje da uobičajena definicija religije kao vjerovanje u Boga nije prihvatljiva, jer ima religija i bez Boga.” Ovim se prof. Šušnjić osvrće na Cvitkovićevu sociologiju religije, na str. 2 svog autorskog priloga pod naslovom: "Teorijsko i istorijsko - razmatranje religiozne vere i nevere". Nadalje, profesor Đuro Šušnjić ističe kako akademik Ivan Cvitković u svojim brojnim radovima upozorava na razliku između crkvenosti i religioznosti. Istraživanja akademika Ivana Cvitkovića su pokazala da je broj onih koji vjeruju svuda mnogo veći od broja onih koji vrše vjerske obrede u crkvi. Prema prof. Đuri Šušnjiću, akademik Ivan Cvitković, kao "poznati i priznati sociolog religije" (3. str. autorskog priloga), "pravi razliku između pojmova religije i vere. Vera se izražava u različitim oblicima: vera u sebe, vera u vođu, vera u naciju, vera u klasu, vera u nauku i sl." Nijedan od ovih oblika vjere, prema stajalištu akademika Ivana Cvitkovića, nema bitne veze sa religioznom vjerom - to je vjera u nešto mistično i apsolutno.

U elaboraciji studije akademika Ivana Cvitkovića pod naslovom "Religija i ne/nasilje" profesor Đuro Šušnjić citira autorovo stajalište po kome "sveti spisi daju uporište za nenasilje", da "religije nisu konfliktne", ali da se religija često zloupotrebljava u političke ciljeve. Akademik Ivan Cvitković se pita: “Ako su pisani religijski izvori okrenuti nenasilju, začuđujuće je otkud toliki broj vjernika sklonih mržnji i nasilju?” Korijeni nasilja, kakvi su se dogodili krajem XX stoljeća na prostorima bivše Jugoslavije, očito su "u lažnom vjerskom identitetu". Zato je put za jačanje nenasilja, kako ističe Hans King, u tome da nema mira među narodima bez mira među religijama. U tom kontek- 
stu akademik Ivan Cvitković zaključuje: "Važna je interpretacija religijskih učenja u skladu sa univerzalnim načelima u čijem središtu je slobodan život i ravnopravnost svih ljudi..."

Prof. dr. Đuro Šušnjić u svom autorskom tekstu navodi: "Dok sam čitao brojne radove akademika Ivana Cvitkovića, uvjerio sam se da ističe potrebu za dijalogom i tolerancijom. Dijalog nije u funkciji nekog spoljašnjeg cilja, već u ulozi razvoja ličnosti. Ko nije kadar da razgovara, taj nije sposoban za razvoj. Voditi tolerantan razgovor o svakom pitanju znači ugrađivati lične i posebne interese u opšte dobro.” Akademik Ivan Cvitković u svojoj knjizi "Religija u zrcalu teorija" iz 2016. godine na str. 32 daje proširenu osnovu ideji tolerancije. Pri tome ističe: "No izađimo iz tolerancije i pođimo k susretanjima. Tolerancija vodi životu jednih pored drugih, susretanja životu s drugima."

Na kraju svoga autorskog teksta, prof. dr. Đuro Šušnjić zapisuje da je akademik Ivan Cvitković "dugo vremena radio i pisao u prilikama koje nikom ne bih poželio..." Cvitković je činio dobro i dobrim i lošim ljudima: “Čovek vredi onoliko koliko ljubavi za druge ima u sebi” (15. str. autorskog teksta). I najzad, u posljednjoj rečenici svog autorskog priloga, prof. dr. Đuro Šušnjić piše: "Ne mogu da odolim iskušenju da on zaslužuje ime Ivan Dobri."

Prof. dr. Ivan Markešić, domaći član ANUBiH, sa radom i životom u Zagrebu, u povodu jubileja: 75. godina života akademika Ivana Cvitkovića piše tekst pod naslovom: “O Čovjeku, znanstveniku i učitelju”. Prof. dr. Ivan Markešić polazi od stajališta da je akademik Ivan Cvitković najveći i najpoznatiji bosanskohercegovački sociolog religije. Iza njegovog naučnoistraživačkog rada i objavljenih knjiga, studija i osvrta stoji brižno analiziranje društvenih, političkih, kulturnih, religijskih zbivanja u Bosni i Hercegovini i njenom okruženju u drugoj polovini XX i na početku XXI stoljeća. Osim uvida u bogatu bibliografiju naučnog opusa, Ivan Markešić u svom autorskom tekstu čini osvrt na više napisanih knjiga (7 knjiga) iz oblasti sociologije religije. Riječ je o sljedećim knjigama: "Sociologija religije", "Sociologija obreda", "Religija u raljama politike", "Religija u zrcalu teorija", "Moj susjed Musliman", "Ganga: pjesma o životu u Hercegovini" i "Ko je bio Alojzije Stepinac". Sve su ove knjige naišle na veliki interes stručne i naučne javnosti. U povodu jubileja: 75. godina života akademika Ivana Cvitkovića, izdvajamo stajališta Ivana Markešića o knjizi: “Moj susjed Musliman”, izdanje Školska knjiga, Zagreb, 2011. godina.

Knjiga se pojavljuje 2011. godine, nakon rušenja njujorških tornjeva. Bilo je to vrijeme zapjenjenih, bučnih i opasnih rasprava o muslimanima i islamu općenito, posebno o vehabizmu i selefizmu, te o mudžahedinima i islamskim 
fundamentalistima. Posmatrano iz današnjeg vremena, bilo je izazovno pisati knjigu sa naslovom: "Moj susjed Musliman”. Ne osvrćući se na zagovornike mržnje prema muslimanima i na sve izraženiju islamofobiju u evropskim društvima, akademik Ivan Cvitković je ponudio evropskim, a time i hrvatskim kršćanima, jedno nemuslimansko objašnjenje ko su zapravo muslimani, u šta vjeruju i kojim se obredom služe. Posebno je važna u knjizi izvedena spoznaja o tome ko su muslimani u Bosni i Hercegovini, u Hrvatskoj i Evropi te kad su i odakle su došli na evropski prostor.

Cvitković je ovom knjigom, navodi Markešić, uspio naučno objasniti i upoznati Evropljane, jednako i kršćane i ateiste i agnostike, zapravo sve one kojima je nepoznata vjera muslimana i njihova religijska kultura, sa onim šta je islam kao vjera, kao kultura i kao civilizacija, kako bi mogli prihvatiti muslimana kao susjeda, kao prijatelja i poznanika, a čak i kao neprijatelja.

Svoj autorski tekst povodom 75. godina života akademika Ivana Cvitkovića pripremio je i akademik Slavo Kukić. U tekstu se na široj osnovi analiziraju naučna stajališta akademika Ivana Cvitkovića koja su oblikovana tokom višedecenijskih istraživanja. Radi se o sljedećim aspektima provedenih istraživanja: nacija i nacionalni identitet; $\mathrm{BiH}$ - prostor isprepletenosti nacionalnog i konfesionalnog; Hrvati i pitanja nacionalnog identiteta; Nacionalizam kao dio bosanskohercegovačke stvarnosti; Međunacionalni odnosi u BiH kao višenacionalnoj zajednici; Dijalog, povjerenje, pomirenje i kultura mira kao conditio sine qua non zajedničke budućnosti.

Akademik Slavo Kukić, kao sociolog sa višegodišnjim bavljenjem sociologijom politike i strukturnim promjenama bosanskohercegovačkog društva u vremenu postratne i postsocijalističke tranzicije, u naučnom opusu Ivana Cvitkovića koji je započeo prije 46 godina knjigom "Društvo, religija i mladi" iz 1974. godine traga za istraživanjima, propitivanjima i odgovorima na krucijalna pitanja u društvenom razvoju bosanskohercegovačkog društva. Zapravo, akademik Slavo Kukić rasvjetljava naučna stajališta akademika Ivana Cvitkovića o naciji i nacionalnom identitetu, posebice nacionalnom identitetu Hrvata. Nadalje se propituju stajališta akademika Ivana Cvitkovića o Bosni i Hercegovini kao prostoru isprepletenosti nacionalnog i konfesionalnog, nacionalizmu kao dijelu bosanskohercegovačke stvarnosti, dijalogu, povjerenju, pomirenju i kulturi mira kao uslovu zajedničke budućnosti.

Višedecenijsko istraživanje međureligijskih i međunacionalnih odnosa u Bosni i Hercegovini omogućuje akademiku Ivanu Cvitkoviću da kreira osnove i pretpostavke izgradnje međunacionalnih odnosa u višeetničkom i višekonfesionalnom društvu. Akademik Slavo Kukić iscrpno interpretira stajališta akademika Ivana Cvitkovića o posljedicama velikosrpskog nacionalizma 
najavljenog u Parlamentu Bosne i Hercegovine 1991. godine Karadžićevom prijetnjom "da će, ako bude rata, nestati muslimanski narod u BiH". Kukić donosi i pregled viđenja velikohrvatskog nacionalizma da su Muslimani $\mathrm{Hr}-$ vati islamske vjeroispovijesti. Izložene su i koncepcije unitarnog uređenja sa dominacijom većinskog bošnjačkog naroda.

U svojoj analizi stajališta akademika Ivana Cvitkovića, Slavo Kukić rasvjetljava ona mjesta kada Cvitković postavlja pitanje: šta je alternativa sadašnjem stanju međunacionalnih odnosa u Bosni i Hercegovini. Pitanje se nadalje konkretizuje: može li se u uvjetima programiranog dizanja međunacionalnih tenzija u predizbornim kampanjama, ali i između njih, graditi odnose međunacionalnog povjerenja i razumijevanja? Rješenje je moguće tražiti u kulturi dijaloga - u spremnosti na kritičko promišljanje o sebi, svojoj lokalnoj zajednici i državi Bosni i Hercegovini kao ustavno-pravnom okviru za mir, zajednički život naroda i napredak u socijalnom razvoju: zapošljavanju, školovanju i sl. 